\title{
THE STATE OF INDUSTRY IN TURKESTAN IN THE EARLY YEARS OF SOVIET RULE
}

\author{
Urol K. Khudoykulov \\ The Associate professor of History Faculty of National University of Uzbekistan
}

Article DOI: https://doi.org/10.36713/epra7076

DOI No: 10.36713/epra7076

\begin{abstract}
The article deals with the history of the industrialization of Turkestan in the $20^{\text {th }}$ years of the $X X^{\text {th }}$ century. Outlines the main directions of the policy of the Bolshevik regime of the Soviets in this area. And also the history of construction of industrial enterprises in the region is given.

KEY WORDS: industry, Turkestan, economy, soviet, Bolshevik regime, Constitution, NEP (New Economic plan), law, machinery and power plants
\end{abstract}

\section{DISCUSSION}

Bolshevik regime needed certain conditions for large-scale industrialization, which initially required the development of the mining industry, metallurgy, the construction of machinery and power plants, as well as urgent work to promote the development of agriculture. The effectiveness of work in the field of industrialization largely depended on the unimaginably complex international relations of the post-World War I period.

The transition period of the economy in the early years of Soviet power was a complex process, which was 1) patriarchal, that is, the main part of which was natural farming; 2) production of small market-related products, mainly by middleclass farmers; 3) private economic capitalism; 4) state capitalism; 5) characterized by socio-economic forms such as socialism, which in the Soviet state at that time consisted mainly of socialist, lowproductivity, capitalist forms[1].

The Soviet Constitution of 1918 stated that one of the main tasks of the new state power was to "determine the foundations and the general plan of all and certain branches of the national economy". The ongoing civil war, the general crisis in industry, the shortage of raw materials, prompted Soviet Russia, first of all, to use fuel and water wisely, and secondly, to move to a more "improved" form of state economy - the planned economy.

Although the Soviet government tried to pay close attention to the development of industry in the national republics in the first year of the NEP, since 1913 more than three-quarters of all industry was concentrated in Moscow, St. Petersburg, Ivanovo, the Urals, and in Turkestan, the Far East, and other remote countries[2].

In the early years of the Soviet regime, the low pace of industry and production in the country, as well as the rarity and scarcity of assets, led to the fact that the industrial sector remained at a much lower level than the Union.

After the First World War, as in Turkestan's agriculture, its industrial sectors and transport were completely destroyed, and the gross industrial output of the province in 1920 decreased by $80 \%$ compared to 1914 . In 1920 , industrial production in the Soviet country was about 7 times less than before the war. Cast iron production in 1921 amounted to $1,163,000$ tons, which was only about $3 \%$ of the smelting of cast iron in the pre-war period. Initially, by 1920 , it was planned to increase coal production by 7.2 times, cast iron production by 68 times, copper smelting by 273 times, and oil production by almost 3 times[3].

For Russia's economic life, Turkestan is a country with promising opportunities rich in textile raw materials3. Turkestan has a low permanent labor force, agriculture, especially in the cotton-growing districts, is almost complex, it is impossible to irrigate lands by artificial (mechanical) water supply or a system of hydraulic structures, mechanized construction without dams and canals. 
Growth indicators of industries[4]

\begin{tabular}{|l|c|c|}
\hline \multicolumn{1}{|c|}{ Area } & $\mathbf{1 9 1 3}$ year & $\mathbf{1 9 2 0}$ year \\
\hline Cast iron smelting (mln. tons) & 4,2 & 0,116 \\
\hline Steel production (mln. tons) & 4,2 & 0,194 \\
\hline Copper production (mln. tons) & 31,1 & 0,3 \\
\hline Coal production (mln. tons) & 29,1 & 8,6 \\
\hline
\end{tabular}

On December 29, 1920, the VIII AllRussian Congress of Soviets announced the end of the Civil War and the beginning of the transition to the restoration of peaceful economic life. The Congress discussed issues of heavy industry, transportation, and agricultural recovery, which were developed by a special commission, and G.M. The popular Russian electrification plan outlined in Krjijanovsky's report is called the GOELRO plan. The Congress also discussed the GOELRO plan, which was approved as the first long-term plan for the national economy of the Soviet state[5]. Later, on February 22, 1921, with the adoption of the "Regulations on the State General Planning Commission", abbreviated as Gosplan, the initial and all efforts were included in the planning system of the Union bodies[6].

The All-Russian Central Executive Committee, the Council of People's Commissars and the Supreme Soviet of National Economy are charged with the task of using joint forces in the implementation of the industrialization plan, as well as developing measures to empower the whole industry[7].

The Soviet government sought to radically change all systems of the national economy through industrialization, to eliminate the disproportion inherited from the past and to create a complex that could meet the new goals and objectives of development, to create a number of new industries for industrial reconstruction, to electrify production. Planned a "complete reconstruction". In developing the fuel balance, it also envisaged concrete measures to dramatically increase its production and rational placement in the country.

Although industrialization has been carried out at an unprecedented rate, it has been said, not only because of the zeal and enthusiasm of the people, but also because of a number of unknown aspects hidden from the public. Most of the builders were prisoners of war, not mobilized "constructionlabor offensive armies" ("stroytrudarmiya"). During the implementation of the program, the rare treasures of the country's culture were largely sold abroad. Also, in many parts of the country, especially during the famine in the Volga region and Ukraine, grain was sold abroad[8], according to some historians. and it would not be possible"[9].

A number of works published in recent years have argued that GOELRO is a promising plan for the development of economic sectors and the electrification of economic regions, which can not be called a plan for electrification. In particular, historian N.S. Simonov (Russia) wrote in a monograph that "10 years after the plan was adopted (1920), Russia plans to increase industrial production to $80 \%$ of the 1913 level, the textile industry to $47 \%$, the chemical industry to $15 \%$, and ferrous metallurgy and machinery to $100 \%$. by 1930 , electricity production was expected to be at least 8.8 billion $\mathrm{kWh}[10]$.

In order to fulfill the plans for 1919-1920, a mechanical plant was established in Tashkent to repair transport and mechanical and foundrymechanical plants on the basis of old semi-handicraft enterprises. In the same year, the repair of diesel engines of the Tashkent tram, as well as power plants in Fergana, Andijan and Samarkand began. All of this was launched as early as the late 1920s[11].

Construction of the Khilkovo cement plant was resumed in1921. The construction of the Fergana silk factory and a hydroelectric power station in Tashkent has begun. The Bekabad cement plant, 9 power plants, 2 metallurgical plants, 2 sewing and 1 silk factories, built in 1924 on the territory of presentday Uzbekistan, were put into operation, etc.[12].

It was on such a backward technical and economic basis that the Soviet state pursued a policy of electrification, and in practice the GOELRO plan was to serve as a basic plan for the development of the national economy for several years to come. Although it is aimed at achieving accurate and clear indicators for the overall direction of development of the national economy and its individual sectors, but as a master plan, the GOELRO plan made its final predictions for individual years and stages of economic development only ten to fifteen years ago (1913)[13].

The "NEP direction", which is a leader in the socialist sector of industrial production, was aimed at large-scale restructuring of management in industry and enterprises on the basis of strict planning and the introduction of economic accounting, which would ensure the som control and some expansion of production democracy[14].

From 1923 to 1924, according to the data on the emergency expenditure of open loans, mainly in the financing of the national economy, throughout the Union, 93853 thousand rubles were distributed to all industries[15]. 
One of the components of the application of reforms in industry was the Leninist idea of "state capitalism"[16]. It provided for the temporary restoration of non-socialist forms of management, but important areas, primarily large-scale industry, remained in the hands of the state, which was the main executor, owner and manager of socialist reconstruction. This hindered competitive forms of ownership and facilitated the unilateral development of industry under state control.

\section{LIST OF USED LITERATURE}

1. Nadtocheev D.I. (1955). Leninskaya politika pervoocherednaya vsemernogo razvitiya tyajeloy industrii $i$ borba partii za ee osushchestvlenii. M.: «Znanie», - C. 13 .

2. 2 The same work. - S. 13.

3. Plan elektrifikatsii RSFSR (Doklad VIII s'yezdu Sovetov Gosudarstvennoy komissii po elektrifikatsii Rossii). Vtoroye izdaniye. - M.: Gos. izd-vo politicheskoy literatury, 1955. - C. 637.

4. Gladkov I.A. (1956). Ot plana GOELRO k planu shestoy desyatiletki. - M.: Izd-vo AN SSSR. -C. 67; Lyashchenko P.I. (1956). History of the national economy of the USSR. T. III. Socialism. - M.: Gos. izd-vo politicheskoy literatury. - P. 91; Nadtocheev D.I. (1955). Leninskaya politika pervoocherednaya vsemernogo razvitiya tyajeloy industrii i borba partii za ee osushchestvlenii. M.: «Znanie»-C. 13; Markin A.B. (1956). Budushchee electrificatisii SSSR. - M.: Gos. izdvo polit. Literature. $-P$. 5.

5. Ekonomicheskaya jizn SSSR. Chronicle of events and facts 1917-1965. V dvux tomax. The book was first published in 1917-1950. - M.: Izd-vo «Sovetskaya ensiklopediya», 1967. - C. 48.

6. Strumlin S.G. Planning in the USSR. - M.: Gos. Izd-vo polit. literature, 1957. - P. 31.

7. Proceedings of the VIII All-Russian Congress of Soviets "On the electrification of Russia" from December 29, 1920. / "Truth". December 31, 1920 №296.

8. Simonov N.S. Development of elektroenergetiki Rossiyskoy empire: predystoriya GOELRO. - M.: Russkiy fond sodeystviya obrazovaniyu i nauke, 2016. - $320 \mathrm{p}$.

9. Simonov N.S. Nachalo elektroenergetiki Rossiyskoy emperii $i$ SSSR, kak problema technotsenoza. - M.: Infra-Engineering, 2017. p. 22.

10. Саидбобоев 3.А. (2010) Тарихий география. Тошкент: Ношир. - Б. 196.

11. Desyatchikov B.A. (1949). Electrification of Uzbekistan. - Tashkent: Uzdavnashr. - B. 18.

12. New history of Uzbekistan. Uzbekistan during the Soviet colonial period. Book 2. - Tashkent: Sharq, 2000. - B. 189.

13. Lyashchenko P.I. (1956). History of the national economy of the USSR. T. III. Socialism. - M.: Gos. izd-vo politicheskoy literatury. - P. 227.
14. Uzbekistan during the Soviet colonial period. New history of Uzbekistan. Book 2. - Tashkent: Sharq, 2000. - B. 188.

15. Саидбобоев 3. (2017). Российские историкогеографические и картографические источники о Средней Азии (первая половина ХIX века) // Сочиосффера. - № 1. - В. 26.

16. Promyshlennost SSSR in 1924 godu. Ejegodnik VSNX. Report of the III Congress of Soviets of the USSR. - M.: Tsentralnoe Upravlenie Pechati, 1925. - C. 10. 